\title{
FISCAL DECENTRALISATION AND ECONOMIC THEORY
}

\author{
Neringa Slavinskaite*
}

\begin{abstract}
.
There is no complete overview or discussion of the literature of the economics of federalism and fiscal decentralization, even though scholarly interest in the topic has been increasing significantly over recent years. This paper provides a general, brief but comprehensive overview of the main insights from the literature on fiscal federalism and decentralization. In doing so, literature on fiscal federalism and decentralization is grouped into two main approaches: "first generation of theories" and "second generation of theories".
\end{abstract}

\section{Introduction}

The basic question addressed by fiscal decentralisation is: What is the optimal allocation of economic responsibilities between different layers of government? The theories are commonly known as theories of fiscal federalism, as the pioneering papers mainly addressed the division of tasks within a federal system of government. However, the theories can be applied much more generally to cover all other forms of intergovernmental relations. For example, in China the greater economic autonomy of regions and local communities seems to be one of the major reasons for its economic success (see Rodrik, 2007, and Ahmad, 1997). In Gelauff et al. (2008), the theory of fiscal decentralisation is applied to the division of tasks between the European Union and national governments. Moreover, the academic study of fiscal decentralization is a field of vigorous research activity and a number of attempts have been made to systematically understand the key economic principles of this area (see, for example, McLure, 1998; Collins, 2001; Boadway, 2003; Bird, 2004). The number of publications on fiscal federalism is much smaller than those for the other key topics such as unemployment, inflation, exchange rate, interest rate and foreign direct investment. However, the area is growing rapidly. In fact, with an average growth rate of about $28 \%$ per annum, fiscal federalism is the second-fastest growing field among these important fields.

The topic of fiscal federalism was generally introduced into public finance theory in the mid twentieth century, which opened the door to the systematic analysis of fiscal decentralization. The main normative question associated with this subject concerns the extent to which fiscal powers and responsibilities should be devolved from higher to lower levels of government. The level of analysis associated with this question has now developed to the extent where scholars have started to distinguish between first and second generation theories of fiscal decentralization (Oates, 2005). The second generation theory of fiscal decentralization

* PhD student of Vilnius Gediminas Technical University, Lithuania. 
is only newly emerging and it does not yet represent a coherent system of analysis, or at least, it has not been well established (see: 1 figure).

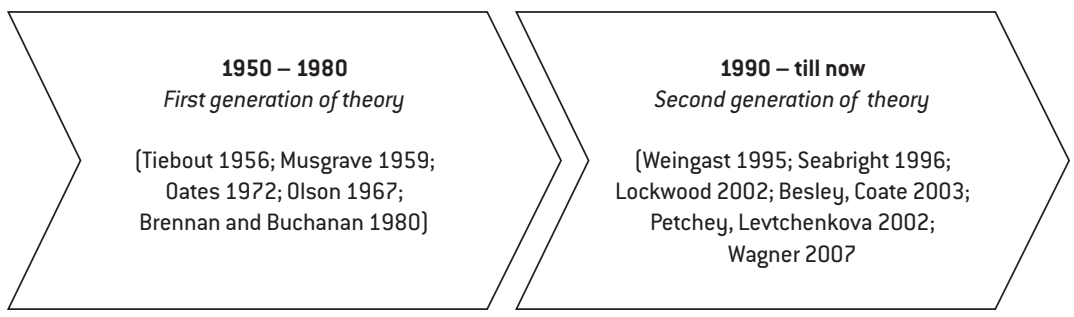

1 figure. First and second generation theory of fiscal federalism

This article offers a critical and in-depth review and evaluation of the important elements of current knowledge and theoretical development of fiscal federalism, with a goal to develop and introduce a refined prototype of fiscal federalism that may be applicable to the different countries.

\section{The first-generation theory of fiscal federalism}

A policy of fiscal decentralization is directed towards the transfer of fiscal powers and responsibilities from the national to subnational governments (SNGs). Among many different economic ideas about decentralization of public functions to SNGs, and the associated issue of public finances under decentralized systems, seminal contributions were made by Tiebout (1956), Musgrave (1959) and Oates (1972), all of whom laid the strong foundation for significant discussions of fiscal decentralization. Olson (1969), through his concept of fiscal equivalence, also made an important contribution. These studies, in conjunction with the public choice approach to multi-tier government initially developed by Brennan and Buchanan (1980) in The Power to Tax - Analytical Foundations of a Fiscal Constitution, represent seminal works in the first generation literature on fiscal decentralization (1 table).

1 table. Researchers of the first generation theories of fiscal federalism (source: author)

\begin{tabular}{|c|c|c|}
\hline Author/Year & Name of book or article & Ideas \\
\hline Tiebout (1956] & A Pure Theory of Local Expenditures & $\begin{array}{l}\text { Introduced the notion of 'impure' or } \\
\text { local public goods and Tiebout sorting' } \\
\text { to the theory of public finance. }\end{array}$ \\
\hline Musgrave (1959) & $\begin{array}{l}\text { The Theory of Public Finance - A } \\
\text { Study in Public Economy }\end{array}$ & $\begin{array}{l}\text { Introduced three different branches } \\
\text { or categories of public finance: econo- } \\
\text { mic stabilization, income distribution } \\
\text { and resources allocation. }\end{array}$ \\
\hline Olson (1969] & $\begin{array}{l}\text { Principle of 'fiscal equivalence': the } \\
\text { division of responsibilities among } \\
\text { different levels of government }\end{array}$ & $\begin{array}{l}\text { Introduced the seminal notion of } \\
\text { 'fiscal equivalence' }\end{array}$ \\
\hline Oates [1972] & Fiscal Federalism & Introduced decentralization theorem \\
\hline $\begin{array}{l}\text { Brennan and Buchanan } \\
\text { (1980) }\end{array}$ & $\begin{array}{l}\text { The Power to Tax - Analytical Founda- } \\
\text { tions of a Fiscal Constitution }\end{array}$ & $\begin{array}{l}\text { Revived the notion of the State as } \\
\text { Leviathan. }\end{array}$ \\
\hline
\end{tabular}


In the influential book The Theory of Public Finance - A Study in Public Economy, Musgrave (1959) introduced three different branches or categories of public finance: economic stabilization, income distribution and resources allocation. These categories are called three main functions of government:

- Allocation function. Musgrave and Musgrave argue that 'although social goods are available equally to those concerned, their benefits may be spatially limited'. Thus, national governments may provide public goods benefiting the total population in the country while local governments produce social goods for their constituencies.

- Distribution function. Redistribution should be conducted by the national government given that spillover effects may render local governments' redistribution function ineffective.

- Stabilization function. Fiscal and monetary policies should be coordinated by the national government in order to maintain economic stabilization.

These branches have come to represent the benchmarks from which issues in public economics are treated by the non-public choice group within their first generation studies of fiscal decentralization. In general terms, each branch is individually subject to consistent theoretical analysis. Between these branches, analytical consistency is more difficult because of diverse and subjective assessments of the relative importance of stabilization, income distributions and efficiency. In the specific public finance perspective on federalism, the Musgravian branches of public finance proved useful in setting the constraints to fiscal decentralization (stabilization and distribution) and the potential benefits of fiscal decentralization (efficiency). Tiebout (1956) introduced the notion of 'impure' or local public goods to the theory of public finance. He did so to analyse political and fiscal decentralization in terms of competition among localities, with the mobility of citizens between localities providing the mechanism for preference revelation. The essence of the Tiebout hypothesis is that consumer demand for local public goods can be revealed when citizens choose the jurisdiction which provides them with the best net benefit. The hypothesis states that, with mobility, consumer-voter's preferences can be revealed and consumers will end up at, or at least close to, the point where their demand for impure public goods is met with due recognition of the costs of supplying this demand. This is now generally known as 'Tiebout sorting'. In summary, Tiebout has made two main contributions to the study of fiscal decentralization. First, he introduced the notion that it is impure public goods that are provided by SNGs. Second, he demonstrated that mobility of taxpayers - voters - between jurisdictions represents the mechanism by which individuals reveal their preference for 'impure' public goods. Olson (1969) introduced the seminal notion of 'fiscal equivalence' to economics within a general framework for investigations of fiscal decentralization. 'Fiscal equivalence' is the notion which posits that, for every collective good, there is a unique 'boundary' for which a separate government is needed, so that 'there can be a match between those who receive the benefits of a collective good and those who pay for it' (Olson, 1969). In broad terms, it positively associates the efficiency goal of public economics with aligning the costs and benefits of impure public good provision with multi-tiered federal systems, each with overlapping physical boundaries, but each with unique boundaries relating to the provision of specific public goods.

The next seminal contribution was made by Oates (1972) in his monograph Fiscal Federalism. Oates implicitly blended Olson's notion of fiscal equivalence with aspects of Tiebout's notion of impure public goods in his theory of fiscal decentralization, although without focusing directly on household mobility or sorting. He argued that there should be a variation of the provi- 
sion of impure public goods and services from governments since inhabitants have different tastes for public services. Oates formalizes his treatment of the issue by defining public goods in a manner that comprises both pure and impure public good attributes. All that matters is that benefits from non-excludable and non-rival public goods are linked to a population in a geographic subset (impure public goods) or the union of population from all such subsets (pure public goods). From this, he developed the decentralization theorem. For a public good - the consumption of which is defined over geographical subsets of the total population, and for which the costs of providing each level of output of the good in each jurisdiction are the same for the central or the respective local government - it will always be more efficient (or at least as efficient) for local governments to provide the Pareto-efficient levels of output for their respective jurisdictions than for the central government to provide any specified and uniform level of output across all jurisdictions (Oates, 1972).

Brennan and Buchanan (1980) revived the notion of the State as Leviathan. They developed the hypothesis that the main interest of the government is to tax heavily so that they have financial resources to spend. In this representation, the government is a monolithic Leviathan, which always seeks to maximize its taxation revenue. Brennan and Buchanan (1980) revived the notion of the State as Leviathan. They developed the hypothesis that the main interest of the government is to tax heavily so that they have financial resources to spend. In this representation, the government is a monolithic Leviathan, which always seeks to maximize its taxation revenue. In response to this issue, the only way to limit the extent of government oversupply, and as a consequence over-taxation, is to constrain governments through effective constitutions that decentralize political and fiscal authority. When political action has the motivational characteristics of Leviathan, political and fiscal decentralization divides, competition between public bodies reduces the force to grow the public sector. In addition, the 'protective state', which establishes the government as enforcer of individual rights and contracts, carries the functions which can be effectively allocated, by competition processes, to the relevant level of government. It is hypothesized that if these protective functions are all assigned to the national government, this government unit has a real incentive to maximize a net surplus because there are no effective controls on its taxing powers. The presence of fiscal decentralization constrains government, encouraging it to devolve to increase the efficiency in providing goods and services to its respective jurisdictional inhabitants; otherwise local citizens will vote on their feet. This contributes an effective constraint on excessive taxing from all government units. As a result, the size of the SNGs, and then the size of the aggregate government sector, decreases.

'Core' first generation theory of fiscal decentralization reveals the above relationship well. However, it does not represent a fully deterministic system for the efficient assignment of responsibilities across various levels of government for the provision of particular services. Only general 'principles' are evident from the efficiency analysis under the first generation theory, with the notion of 'fiscal equivalence' being an especially important concept. In general, five main principles of fiscal decentralization may be deduced from 'core' first generation theory:

- First, pure nationally bounded public goods are more efficiently provided by the national government (Bird, 2000). For example, foreign policy, defence, immigration and international trade can be best formulated and implemented by the national government. Services should be provided by the national government when demand is at a constant level across the various subnational localities. In addition, centralized provision of public services also 
experiences a great benefit from economies of scale.

- Second, based on the principle of fiscal equivalence and Oates's decentralization theorem, the geographic boundaries of the diverse range of local public goods should align (as far as possible] with political boundaries of the second-tier governments (states) and the third-tier governments (local governments). SNGs are able to provide a range of services to local communities such as law, order and public safety, education, health policy, as well as very local issues such as the street lighting system, local sewerage, garbage collection, and local paper deliveries. Importantly, variations in the level of provision of public services across subnational regions provide a basis for partially redressing [i] spill-over effects and (ii) congested effects.

- Third, public provision of both pure 'private' goods and impure SNGs' public goods and services should be based on the size of jurisdiction, and in accordance with local tastes and preferences (Shah, 2004). If the size of jurisdiction is considered, the principle of benefit matching is achieved because local citizens who receive benefits also bear costs. A system of fees and user charges may also be useful and effective for the purpose of cost recovery (McLure and Martinez-Vazquez, 2004). SNGs operate closely to local inhabitants so that they are the sole agents, who are in the best position to understand preferences, tastes and the amount demanded. Once the 'benefit areas' can be established, local provision on the basis of cost recovery tailors local service provision to the demands of local people. This enhances economic efficiency. Related to this, local provision of public services may also result in experimentation, and then innovation, to promote efficiency in public policy for the entire economy (Oates, 1999). This suggests that devolution may also have 'dynamic' efficiencies.

- Fourth, the assignment of responsibility for the various types of service delivery must be transparent and clearly understood and agreed by all parties. Failure to do so results in the overlapping of publicly provided services. Clear assignment of responsibility for service provision limits co-sharing responsibilities, where more than one level of government gets involved in the same areas of spending (Martinez-Vazquez, 2001). Co-sharing, while sometimes unavoidable, can lead to ambiguity which creates unnecessary coincidence in providing public services to local communities, and, in turn, negatively affects the efficiency of the spending programmes. It may even be used to intentionally confuse the responsibilities of each level of government. This may result in fiscal illusion - local citizens may misjudge the 'true' benefits and costs of their government (Dollery and Worhington, 1999). Two effects associated with the notion of a citizen's fiscal illusion are widely recognized (Turnbull, 1998). First, public spending is maintained at a greater level under fiscal illusion compared with perfect information - the overspending effect. Related to this is the 'flypaper effect', which is the prediction that intergovernmental grants from high level government usually stimulate more local spending than locally generated revenue. Clear assignment of responsibility alone does not necessarily overcome the problem of fiscal illusion.

- Fifth, the economies of scale of local production of goods and services, including the related issues of local financial, managerial and administrative capabilities, should also be considered. This is particularly important for developing economies. As such, asymmetric spending assignment may be appropriate. That is, service delivery responsibility may be different across the same level jurisdictions when there are different economies of scale and administrative capacities across governments within the same level of SNGs. However, 
in reality, countries which adopt this type of spending assignment usually do so for political and/or geographical reasons (Joumard and Kongsrud, 2003).

Musgrave (1959), Oates (1972), Olson (1969) and Tiebout (1956) clarify that neither a largescale centralised government nor a fully decentralised government consisting of many small and local jurisdictions is likely to be efficient. The central government should focus on providing national public services, i.e. services whose benefits extend nation-wide or whose provision is subject to substantial economies of scale. Common examples are defence, foreign affairs, national infrastructure, monetary policy, macroeconomic stabilisation, and policies for income redistribution and poverty. Decentralisation versus centralisation according to the fírst generation of theories are summarised in Table 2.

\section{2 table. Decentralisation versus centralisation according to the fírst generation of theories} (source: Bos 2012)

\begin{tabular}{|c|c|}
\hline Advantages of decentralization & Advantages of centralization \\
\hline \multicolumn{2}{|l|}{$\begin{array}{l}\text { Stimulates preference matching for local public } \\
\text { services, in particular when preferences are hete- } \\
\text { rogeneous. }\end{array}$} \\
\hline $\begin{array}{l}\text { Public services with limited external effects and } \\
\text { geographical spillovers should be provided locally. }\end{array}$ & $\begin{array}{l}\text { Public services with large external effects and geo- } \\
\text { graphical spillovers should be provided centrally. }\end{array}$ \\
\hline $\begin{array}{l}\text { Cross-border externalities of local public services } \\
\text { may be partly internalised by voluntary contribu- } \\
\text { tions and negotiation. }\end{array}$ & $\begin{array}{l}\text { Cross-border externalities of local public services } \\
\text { can be internalised without need for voluntary } \\
\text { contributions and negotiation. }\end{array}$ \\
\hline \multicolumn{2}{|l|}{$\begin{array}{l}\text { Public servises that can be financed by charges or } \\
\text { land rent tax should be provided locally. }\end{array}$} \\
\hline \multicolumn{2}{|l|}{$\begin{array}{l}\text { Local service charges, high local taxes and mobility } \\
\text { stimulate preference matching and policy compe- } \\
\text { tition. }\end{array}$} \\
\hline $\begin{array}{l}\text { Local autonomy of borrowing leads via the capital } \\
\text { market to fiscal discipline of local units. }\end{array}$ & $\begin{array}{l}\text { Hierarchy and restrictions on local borrowing can } \\
\text { ensure fiscal discipline of local units. }\end{array}$ \\
\hline Economies of scale by voluntary co-operation. & $\begin{array}{l}\text { Economies of scale without need for voluntary co } \\
\text { operation; uniform policy serves efficiency. }\end{array}$ \\
\hline $\begin{array}{l}\text { Policy competition stimulates policy learning, } \\
\text { preference matching and efficiency. }\end{array}$ & $\begin{array}{l}\text { Policy learning at central level due to exchange of } \\
\text { infornation and and commitment building. }\end{array}$ \\
\hline $\begin{array}{l}\text { Public services for which costs of information and } \\
\text { decision making increase with the number of partici- } \\
\text { pants should be provided locally. }\end{array}$ & $\begin{array}{l}\text { Public services for which costs of information and } \\
\text { decision making remain low when the number of } \\
\text { participants increases should be provided centrally. }\end{array}$ \\
\hline \multirow[t]{2}{*}{$\begin{array}{l}\text { Stimulates political participation and helps to } \\
\text { protect basic liberties and freedoms. }\end{array}$} & $\begin{array}{l}\text { More efficient taxation and fiscal and monetary } \\
\text { policy. }\end{array}$ \\
\hline & $\begin{array}{l}\text { Uniform level of public services, taxes and social } \\
\text { security serves equity and allows redistribution } \\
\text { from rich to poor regions and jurisdictions. ; Public } \\
\text { services with a redistributive character (e.g. edu- } \\
\text { cation and heaith care) should be provided centrally. }\end{array}$ \\
\hline
\end{tabular}


In short, the first generation theory of fiscal decentralization suggests that, in general, service provision responsibilities are best assigned to the lowest level of government that can meet the service responsibility efficiently. Oates's decentralization theorem has laid a strong foundation for the study of fiscal federalism and decentralization, all of which developed from the general literature on public economics. The result was what is now called the first generation theory of fiscal decentralization.

\section{The second-generation theory of fiscal federalism}

Towards the end of the last decade of the twentieth century, a 'second' generation theory of fiscal decentralization has begun to emerge, which draws on ideas from outside the public finance literature. As Oates (2005) has highlighted, this second generation began investigating fiscal decentralization by drawing on notions from the theory of the firm, the economics of information, the principal-agent problem, and the theory of the contract.

Two main considerations underlie the development of the second generation theory (Oates, 2005):

- The first concerns the political processes and the behaviour of political agents in which participants may have their own objective functions. Government officials may not need to seek the common good as assumed in the first generation theory; rather, they may not act to maximize the welfare of their constituencies. This consideration has obvious links to public choice theory - which was the main 'non-core' stream of the first generation theory of fiscal decentralization.

- The second concerns the issue of asymmetric information and political agents. Some particular participants have more knowledge of local preferences and tastes and cost structure compared to the others.

To examine these influences, fiscal federalism is examined from the perspective of a framework on industrial organization and microeconomic theory. While the general support for fiscal decentralization in the first generation theory is acknowledged, the dangers of going too far in the fiscally decentralized system are a feature of the second generation theory.

The emerging second generation theory has been characterized in terms of two motivating issues: incentives and knowledge $(\mathrm{Vo}, 2008)$. Both motivations have contributed to an increased economic efficiency: incentives are required for SNGs to do a better job to avoid outward migration of people and firms; and knowledge of local preferences and tastes is crucial to achieve economic efficiency when local public goods and services are provided by SNGs. The contributions of the second generation theory are mainly drawn from the economics of transaction cost incomplete contracts and principal-agent perspectives $\left(\mathrm{V}_{0}, 2008\right)$. Leading studies, that have been classed as parts in the emerging second generation theory, are associated with Weingast (1995), Seabright (1996), Lockwood (2002), Petchey and Levtchenkova (2002), Besley and Coate (2003) and Wagner (2007) (see 3 table). 
3 table. Researchers of second generation theories of fiscal federalism (source: author)

\begin{tabular}{|c|c|c|}
\hline Author/Year & Name of book or article & Ideas \\
\hline Weingast (1995] & $\begin{array}{l}\text { The economic role of political institu- } \\
\text { tions: market-preserving federalism } \\
\text { and economic development. }\end{array}$ & $\begin{array}{l}\text { Introduced the notion of market } \\
\text { preserving federalism to investigate } \\
\text { how competing jurisdictions create } \\
\text { incentives for credible commitment } \\
\text { and lower transaction costs. }\end{array}$ \\
\hline Seabright (1996) & $\begin{array}{l}\text { Accountability and decentralisation in } \\
\text { government: an incomplete contracts } \\
\text { model. }\end{array}$ & $\begin{array}{l}\text { Introduced the notion of 'incomplete } \\
\text { contract' to the analysis of fiscal } \\
\text { federalism and presents elections } \\
\text { as incomplete contracts in which } \\
\text { some information, in the 'contract', is } \\
\text { unverifiable. }\end{array}$ \\
\hline Lockwood [2002] & $\begin{array}{l}\text { Distributive politics and the costs of } \\
\text { centralisation. }\end{array}$ & $\begin{array}{l}\text { Confirms Oates' insights that decen- } \\
\text { tralization is the more efficient arran- } \\
\text { gement when externalities are small } \\
\text { and/or regions are heterogenous. } \\
\text { However, the conditions required for } \\
\text { increased heterogeneity to imply } \\
\text { increased efficiency of decentraliza- } \\
\text { tion are strong, essentially because } \\
\text { the cost of centralization is not policy } \\
\text { uniformity, but inefficient choice of } \\
\text { projects due to cost-sharing and lack } \\
\text { of responsiveness of the legislative } \\
\text { process to benefits. }\end{array}$ \\
\hline Besley and Coate (2003) & $\begin{array}{l}\text { Centralized versus decentralized pro- } \\
\text { vision of local public goods: a political } \\
\text { economy approach. }\end{array}$ & $\begin{array}{l}\text { Offered an alternative vision of } \\
\text { the drawbacks of centralization, } \\
\text { stemming from political economy } \\
\text { considerations. }\end{array}$ \\
\hline $\begin{array}{l}\text { Petchey and Levtchenko- } \\
\text { va [2002] }\end{array}$ & $\begin{array}{l}\text { The welfare effects of fiscal equalisa- } \\
\text { tion in a federal economy with factor } \\
\text { mobility and strategic behaviour. }\end{array}$ & $\begin{array}{l}\text { Introduces fiscal equalization, and } \\
\text { pointed out that equalization grants } \\
\text { are not determined exogenously. }\end{array}$ \\
\hline Wagner [2007] & $\begin{array}{l}\text { Fiscal Sociology and the Theory of } \\
\text { Public Finance: An Exploratory Essay. }\end{array}$ & $\begin{array}{l}\text { Shifted attention away from 'tiers' } \\
\text { of government, and assignment of } \\
\text { powers and responsibilities across } \\
\text { tiers, to focus on the competing 'poly- } \\
\text { centric' character of government. }\end{array}$ \\
\hline
\end{tabular}

Following Qian and Weingast (1997), second-generation theory has been inspired by two theories:

- First, Hayek (1945) suggested that because local governments have more knowledge about their population's preferences, they are in a better position to provide public services effectively. Thus, local governments shouldshoulder the main responsibilities of public services.

- Second, citizens' sorting process presses local governments to respond to local needs as noted by Tiebout (1956). This argument posits that citizens may move out from localities 
that provide inferior public services while taxing a lot. Those places that match citizens' preferences mostly will be the destination due to the sorting process. 'Votes with feet' create great pressure on local governments to respond to various needs since citizens' taxes are important sources of government revenues. The sorting process and inter-jurisdictional competition are beneficial for a better government. Thus, local governments should be empowered to perform effectively and reduce the possibility of sorting out.

Based on the above assumptions, central governments should constrain themselves to a limited area, such as macroeconomic management and policing the common market within the country. More importantly, many believe that empowering local governments may enhance the accountability and transparency of the governmental system (Hankle 2009) As citizens are more capable of collecting information about the performance of local governments and imposing sanctions on them through a sorting process or election systems, fiscal decentralization is beneficial to improve accountability, which is critical to quality governance.

Among others, 'market-preserving federalism' can be regarded as one of the most important theories contributing to the second generation of fiscal federalism.

Weingast (1995) introduced the notion of market preserving federalism to investigate how competing jurisdictions create incentives for credible commitment and lower transaction costs. Assuming a hierarchy of governments (at least two levels of government rule the same land and people) with autonomy of each level of government institutionalized, Weingast modelled the market preserving federalism. The main findings, for the UK and the USA are (i) federalism provides the political basis for the common market; (ii) the prohibitions against the national government's exercise of economic regulation greatly reduced the government's political responsiveness to interest groups; and (iii) the prohibitions on internal trade barriers allowed entrepreneurs, new enterprises, and new economic activities to emerge in new areas that could outcompete interests in older areas (Weingast, 1995).

In contrast, Seabright (1996) introduced the notion of 'incomplete contract' to the analysis of fiscal federalism. The author presents elections as incomplete contracts in which some information, in the 'contract', is unverifiable. Political accountability can be an organizational motivation for decentralization. In contrast, centralization could be more preferred when the mechanisms associated with incomplete contract provide greater scope for policy cooperation between different levels of government to internalize inter-jurisdictional fiscal externalities. As a consequence, the decision on preferred mechanism depends on the relative magnitude between benefits from internalization of inter-jurisdictional fiscal externality and costs arising due to a reduced accountability under fiscal centralization.

The starting point for Lockwood (2002) and Besley and Coate (2003) is Oates's decentralization theorem, but these authors correctly pointed out that goods and services provided by the national government are not necessarily homogeneous, as Oates had originally assumed. Once it is recognized that national provision of public goods and services is possible on a differential basis between regions, a different fiscal framework is needed from that developed by Oates. In their frameworks, output provided by the national government consists of locally designed outputs which are determined by the central legislation. This is feasible because the national government body always consists of locally elected representatives from local regions. Nevertheless, the broad thrust of Oates's findings on the efficiency of decentralized fiscal arrangement is reproduced in models in which inter-jurisdictional externalities are small and regions are heterogeneous. 
Besley and Coate (2003) presented paper "Centralized versus decentralized provision of local public goods: a political economy approach "which takes a fresh look at the trade-off between centralized and decentralized provision of local public goods. It argues that the sharing of the costs of local public spending in a centralized system will create a conflict of interest between citizens in different jurisdictions. When spending decisions are made by a legislature of locally elected representatives, this conflict of interest will play out in the legislature. Depending on precisely how the legislature behaves, the result may be excessive public spending or allocations of public goods characterized by uncertainty and misallocation across districts. The extent of the conflict of interest between districts is affected by spillovers and differences in tastes for public spending. Thus, the relative performance of centralized and decentralized systems depends upon spillovers and differences in tastes for public spending. Lockwood (2002) presented paper "Distributive politics and the costs of centralisation". This paper has presented a model where the relative merits of centralization and decentralization, and the performance of various constitutional rules for choosing between the two, can be evaluated. They presented a fully explicit model of a national legislature, where legislative rules, rather than behaviour, are taken as primitive. An important finding is that the uniformity of provision is endogenously determined by the strength of the externalities. When externalities are large and positive, an outcome closer to universalistic provision, rather than just a bare majority of funded projects, will occur. Moreover, this characterization of the behaviour of the legislature is robust to the introduction of logrolling, and of different specifications of the legislative rules. This model allows to investigate in detail both the relative efficiency of centralization and decentralization, and of the performance of various constitutional rules for choosing between them. To some extent, our analysis confirms Oates' insights that decentralization is the more efficient arrangement when externalities are small and/or regions are heterogenous. However, the conditions required for increased heterogeneity to imply increased efficiency of decentralization are strong, essentially because the cost of centralization is not policy uniformity, but inefficient choice of projects due to cost-sharing and lack of responsiveness of the legislative process to benefits.

Another contribution to second generation theory of fiscal decentralization is evident from recent studies of Australian fiscal equalization by Petchey and Levtchenkova (2002, 2004), which pointed out that equalization grants are not determined exogenously. This is because equalization is undertaken with respect to a fiscal standard that is determined in relation to actual fiscal behaviour. In this circumstance, there is an incentive for the states to behave strategically in their fiscal decisions. This provides the basis for an 'equalization game' which takes into account states' strategic behaviour and provides a basis for developing proposals which enhance efficiency. The generally accepted view now is that the presence of the second generation theory of fiscal decentralization classifies, rather than contradicts, the validity of the first generation, including the decentralization theorem: Although the models under the second generation theory umbrella differ in fundamental ways from the first generation theory, many of them produce a trade-off between centralisation and decentralisation that is in a somewhat similar spirit to their earlier counterparts (0ates, 2005).

Finally, a second generation of public choice theory is also emerging. This is mainly associated with the work of Wagner (2007), which shifts attention away from 'tiers' of government, and assignment of powers and responsibilities across tiers, to focus on the competing 'polycentric' character of government. This is associated with a focus on the process by which diverse 
centres of government respond to demands for publicly provided services in a manner that is integrated within the market economy. Wagner's basic view on the evolutionary character of polycentric government is more important than the hierarchical aspect of government in which the questions of which functions to be provided at the national and subnational levels of government are addressed (Wagner, 2007), as it is in the conventional approach to fiscal decentralization. The process by which governments respond to emerging demand from the community is directly linked to the capacity to raise their own revenue in an innovative way. Moreover, the focus is on government 'enterprise', in which some government units fulfil the role of public service producers and some take on the role of the articulators of the public services (Wagner, 2007).

\section{Concluding Remarks}

The key point to note is that the notion of decentralization plays a very important role in the theory of fiscal federalism; irrespective of whether core or non-core first or second generation theory is being considered, decentralization is the primary issue of concern.

The paper provides a general and brief overview of the main insights from the literature on fiscal decentralization with the focus exclusively on theoretical developments of fiscal federalism and decentralization. It reveals the findings from the first generation theory, as represented by seminal studies from Musgrave, Tiebout, Olson and Oates, 'fiscal equivalence', population sorting and the fiscal decentralization theorem.

It also points to the public choice stream of first generation theory and an emerging second theory of fiscal decentralization, which mainly concerns the efficiency trade-off between fiscal centralization and decentralization.

Leading studies, that have been classed as parts in the emerging second generation theory, are associated with Weingast (1995), Seabright (1996), Lockwood (2002), Petchey and Levtchenkova (2002), Besley and Coate (2003) and Wagner (2007). The 'second' generation theory of fiscal decentralization has begun to emerge in end of the last decade of the twentieth century, which draws on ideas from outside the public finance literature.

\section{REFERENCES}

1. Ahmad, E. (1997) “China”, Chapter 26, in T. Ter-Minassian (ed.). Fiscal Federalism in Theory and Practice, International Monetary Fund, Washington, DC, 634-659.

2. Besley, T., Coate, S. (2003) Centralized versus decentralized provision of local public goods: a political economy approach. Journal of Public Economics 87: 2611-2637.

3. Bird, R. (2000) Intergovernmental fiscal relations: universal principles, local applications. Working Paper No. 00-2, International Studies Program, Andrew Young School of Policy Studies, Georgia State University

4. Bird, R. (2004) Transfers and incentives in intergovernmental fiscal relations. Available at www.fiscalreform.net.

5. Boadway, R. (2003) National taxation, fiscal federalism and global taxation. The WIDER Project on Innovation Sources of Development Finance, Queen's University, Canada

6. Boss F. (2012) Economic theory and four centuries of fiscal decentralisation in the Netherlands. OECD journal of Budgetring. 2

7. Brennan, G., Buchanan, J. M. (1980) The Power to Tax - Analytical Foundations of a Fiscal Constitution. Cambridge: Cambridge University Press

8. Collins, D. J. (2001) The 2000 reform of intergovernmental fiscal arrangements in Australia. Paper presented for the International Symposium in Quebec, Canada, September.

9. Dollery, B., Worhington, A. (1999) Fiscal illusion at the local level: an empirical test using Australian municipal data. Economic Record 75: 37-48. 
10. Gelauff, G., Grilo I., Lejour A. (eds.) (2008) Subsidiarity and Economic Reform in Europe, Springer- Verlag, Berlin

11. Hayek F. A., 'The use of knowledge in society', American Economic Review XXXV[4], (1945), pp. 519-530.

12. Hankla Ch. R., 'When is fiscal decentralization good for governance?', Publius: Journal of Federalism 39(4), (2009), pp. 632-650.

13. Joumard, I. and Kongsrud, M. (2003) Fiscal relations across government levels. Economics Department Working Papers No. 375, OECD.

14. Lockwood, B. (2002) Distributive politics and the costs of centralisation. Review of Economic Studies 69(2): 313-337.

15. Martinez-Vazquez, J. [2001) The assignment of expenditure responsibilities. Andrew Young School of Policy Studies, Georgia State University.

16. McLure, C. (1998) The revenue assignment problem: ends, means, and constraints. Journal of Public Budgeting, Accounting and Financial Management 9[4]: 652-683

17. McLure, C., Martinez-Vazquez, J. (2004) The Assignment of Revenues and Expenditures in Intergovernmental Fiscal Relations. Washington, DC: World Bank

18. Musgrave, R. A. (1959) The Theory of Public Finance - A Study in Public Economy. New York: McGraw-Hill.

19. Oates, W. E. (1972) Fiscal Federalism. New York: Harcourt Brace Jovanovich.

20. Oates, W. E. (1999) An essay on fiscal federalism. Journal of Economic Literature 37: 1120-1149.

21. Oates, W. E. (2005) Toward a second-generation theory of fiscal federalism. Journal of International Tax and Public Finance 12: 349-373.

22. Olson, M. (1969) The principle of 'fiscal equivalence': the division of responsibilities among different levels of government. American Economic Review 59: 479-487.

23. Petchey, J., Levtchenkova, S. (2002) The welfare effects of fiscal equalisation in a federal economy with factor mobility and strategic behaviour. Mimeo, School of Economics and Finance, Curtin University

24. Qian, Y.; Weingast B. R., (1997). Federalism as a commitment to preserving market incentives', Journal of Economic Perspectives 11(4): 83-92

25. Rodrik, D. (2007), One Economics, Many Recipes: Globalization, Institutions, and Economic Growth, Princeton University Press, Princeton, New Jersey, United States.

26. Seabright, P. (1996) Accountability and decentralisation in government: an incomplete contracts model. European Economic Review 40: 61-89.

27. Shah, A. (2004) Expenditure Assignment. Intergovernmental Fiscal Relations and Local Financial Management Program. Washington, DC: World Bank.

28. Tiebout, C. M. (1956) A pure theory of local expenditures. Journal of Political Economy 64: 416-424.

29. Turnbull, G. K. (1998) The overspending and flypaper effects of fiscal illusion: theory and empirical evidence. Journal of Urban Economics 44: 1-26.

30. Vo, D. (2008) Fiscal decentralisation indices: a comparison of two approaches. Rivista di diritto finanziario e scienza delle finanze LXVII: 3, I, 295-323.

31. Wagner, R. (2007) Fiscal Sociology and the Theory of Public Finance: An Exploratory Essay. Cheltenham: Edward Elgar.

32. Weingast, B.R. [1995] The economic role of political institutions: market-preserving federalism and economic development. Journal of Law, Economics and Organisations 15(1): 1-31. 